\title{
A Comparative Study of Serum Cystatin C, Serum Electrolytes, Urea and Creatinine in Early Detection of Kidney Injuries in Albino Rats Exposed to Formaldehyde
}

\author{
Michael Chinedu Olisah ${ }^{1}$ and Samuel C. Meludu ${ }^{2}$ \\ ${ }^{1}$ Department of Medical Biochemistry and Chemical Pathology, Chukwuemeka Odumegwu Ojukwu University, Uli. \\ ${ }^{2}$ Department of Human Biochemistry, Nnamdi Azikiwe University, Nnewi Campus.
}

*Correspondence: olisemike2007@yahoo.com; mobile no: +234(0)8038884404

\begin{abstract}
Aim: To ascertain early detection of possible kidney injuries in albino rats exposed to formaldehyde by assessing cystatin $\mathrm{C}$, serum electrolytes, urea and creatinine. Materials/Methods: Thirty healthy adult male albino rats, weighing between 100 to 120 grams were randomly divided into three groups A, B and C. Group A served as control. Group B was exposed to low dose (100ppm of Formaldehyde), $3 \mathrm{hrs}$ per day for four weeks, while group C was exposed to high Dose-200ppm of formaldehyde $3 \mathrm{hrs}$ per day for four weeks. At the end of the exposure period, the rats were sacrificed by decapitation under chloroform anesthesia, and 4 $\mathrm{ml}$ of blood samples was collected from each rat into a plain bottle. The whole blood was allowed to clot, retracted and centrifuged at $3000 \mathrm{rpm}$ for 10 minutes and serum separated. The serum was stored at $-20^{\circ} \mathrm{C}$ until analyses for serum electrolytes, creatinine and cystatin C. Serum electrolytes were determined using Ion selective electrode, urea and creatinine were determined using spectrophotometric methods while cystatin C was analyzed using Eliza. Data obtained was analyzed using SPSS. Results: The concentrations of the serum electrolytes, sodium. Potassium, bicarbonate and chloride were compared across the three group, they were not statistically significant $(\mathrm{p}>0.05)$. Urea was significantly higher in group $\mathrm{C}$ when compared with low dose $\mathrm{B}$ and control group A $(\mathrm{P}<0.05)$. Also, when the low dose group B was compared with the high dose group $\mathrm{C}$, it was statistically significant. Creatinine concentrations were significantly higher in group $\mathrm{C}$ when compared with the control group A, while group B was not significant when compared with group A. Finally, the cystatin $\mathrm{C}$ concentrations were also significant when groups B, C were compared with the control group. Conclusion: Formaldehyde exposures may induce a gradual deterioration of renal functions in chronically exposed albino rats. Serum electrolytes, urea and creatinine may not be sufficient to indicate an early signs of kidney damage. From the study, serum cystatin $\mathrm{C}$ may be a better marker of renal impairment in early stages.
\end{abstract}

Keywords: Formaldehyde, Kidney failure, Electrolytes, Cystatin $C$.

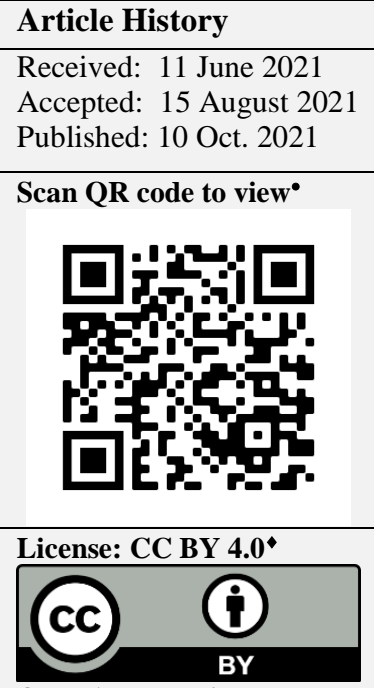

Open Access article.

How to cite this paper: Olisah, M. C. and Meludu, S. C. (2021) A Comparative Study of Serum Cystatin C, Serum Electrolytes, Urea and Creatinine in Early Detection of Kidney Injuries in Albino Rats Exposed to Formaldehyde. IPS Journal of Toxicology, 1(1), 1-4. https://doi.org/10.54117/ijt.v1i1.1.2021

\section{Introduction}

Formaldehyde was discovered in 1867 by the British chemist, August Wilheld Von Hofmann, it is a colorless gas, has flammable properties and irritating repugnant odor (IARC, 2006). The chemical is mainly used to preserve cadavers in Departments of anatomy and in most mortuaries (Raja, 2012). The use of formaldehyde solutions as fixative for biological specimens is a common practice across the globe, especially for the developing countries where infrastructure is often inadequate and the unstable supply of electricity has also reduced the options for preservative techniques. Thus anatomists, technicians in biological science laboratories, morticians in embalming centres and medical school students in dissection hall are regularly exposed to formaldehyde (Onyije et al., 2012; Elshaer and Mahmoud, 2017). The threshold limit value for formaldehyde is 0.3 ppm, which must never be exceeded (USEPA, 2010). In the body, formaldehyde quickly metabolizes to formic acid (Girish et al., 2014). The measurement of formate levels indicates the severity of formaldehyde intoxication.

ROS are key participants in the damage caused by toxic gases (e.g. formaldehyde and benzene). These ROS can be enzymatically bioactivated to reactive intermediates that can lead to increased formation of ROS (Rana et al., 1995). Decrease in the protective mechanisms by these antioxidants will lead to oxidative stress with pathological consequences. Chronic formaldehyde exposure may induce necrosis in the kidney, and may also induce apoptosis or autophagy (Ramos et al., 2017). The exact mechanism of toxicities is dependent on the cell type involved, the dose and the length of exposure, which is true of all toxicants (Linkermann $e t$ 
al., 2014; Sancho-Martinez et al., 2015). Major health impacts have been reported by the National Institute of Occupational Safety and Health (NIOSH, 1977) due to formaldehyde exposure including nervous, reproductive, skin, kidney and liver damage. In addition, Lauwerys et al., (1985) have described several nephrotoxic effects of Formaldehyde that cause cellular injury within the tubules and glomeruli including epithelial enlargement, ballooning and hydrophilic necrosis. The exposure to formaldehyde in a short period of time leads to changes in the kidney function, inflammation and morphology, as well as promote the increase of superoxide dismutase activity and oxidative damage in rats (Olisah et al., 2017; Ramos et al., 2017). Toxic agents can also induce accumulation of lipid in the renal tubular epithelium, thus damaging kidney function (Jones et al., 1996). The society, especially the southern part of Nigeria has developed the culture of keeping their dead relation for months before burial, hence the increase in mortuaries and use of formaldehyde. Morticians solely depend on this method for preservation of corpses. Furthermore, the following researchers, Osadolor et al. (2014); Euphoria et al. (2015); Olisah et al. (2020) reported on some oxidative stress markers and liver enzymes in morticians exposed to formaldehyde in southern Nigeria, there is need to assess the kidney function especially using newer marker for early detection of kidney toxicity from formaldehyde exposure.

\section{Materials and Methods}

Thirty healthy adult male albino rats, weighing between 100 to 120 grams were obtained from animal house of Department of Physiology, University of Nigeria Nssuka. All the animals were transported in a well -ventilated cage with steady supplier of feeds. They were acclimatized for 7 days prior to the commencement of exposure and were also maintained under controlled conditions with $12 \mathrm{hr}$ light and $12 \mathrm{hr}$ dark cycles at room temperature of $25 \pm 2{ }^{\circ} \mathrm{C}$ and relative humidity of 30-70\%. Standard chow from vital feeds and water were given ad libitum. Experimental design: Standard inhalation procedures were followed according to the exposure protocol described by Uboh et al. (2005). All experimental animals were housed in stainless steel cages $(60 \mathrm{~cm} \times 30 \times 40 \mathrm{~cm})$ in a well-ventilated animal house with free access to water, and normal rat chow. The animals were randomly divided into three groups (A, B, and C) each consisting of ten animals. Group A served as control and was kept in a section of the experimental animal house free from formaldehyde fumes. Group B was exposed to low dose (100ppm of Formaldehyde) for four weeks, while group C was exposed to high Dose-200ppm of Formaldehyde for four weeks. The time exposure to vapours of formaldehyde was 3 hours per day (9am to 12noon), after which the animals were transferred to fumes-free section of the experimental animal house.

Method of Exposure: The method of exposure employ in this study was by inhalation.

The animal cages housing the test groups were placed in exposure chambers measuring $150 \mathrm{~cm} \times 90 \mathrm{~cm} \times 200 \mathrm{~cm}$. Two highly perforated $1000 \mathrm{ml}$ cans containing $500 \mathrm{ml}$ of formaldehyde with different concentrations (low dose-100ppm, and High Dose-200ppm) were placed in the two different exposure chambers and the animals were allowed to inhale the fumes evaporating from the cans. After exposures, the animals were sacrificed. Control animals were housed in similar conditions but in a cage without the exposure chamber.

At the end of the 4-weeks exposure period, the rats were sacrificed by decapitation under chloroform anesthesia, and $4 \mathrm{ml}$ of blood samples was collected from each rat into a plain bottle. The whole blood was allowed to clot, retracted and centrifuged at $3000 \mathrm{rpm}$ for 10 minutes and serum separated. The serum was stored at $-20^{\circ} \mathrm{C}$ until analyses for serum electrolytes, urea, creatinine and cystatin C. Serum electrolytes were determined using Ion selective electrode, urea and creatinine were determined using spectrophotometric methods while cystatin $\mathrm{C}$ was analyzed using Eliza. Data obtained was analyzed using SPSS version 21. Descriptive statistics and ANOVA were performed and results expressed as Mean \pm SD (Standard deviation). In all cases, the difference was considered statistically significant at $\mathrm{p}<0.05$.
All the chemicals used in the present study were procured from Hi Media Laboratories, India and only Analytical Grade (AR) reagents were used. The analyses were done at Chemical Pathology Department, Nnamdi Azikiwe University teaching Hospital, Nnewi, Anambra State.

\section{Results and Discussion}

The physical changes observed in the animals include discolouration of skin, sluggishness in movement and decrease in feeding habit. These changes were prominent among those animals exposed to higher concentration than those exposed to lower concentration. Thus Formaldehyde exposures may cause alterations in normal physiologic functions.

The mean weights of animals are statistically significant when the base line weights are compared with that after exposures $(\mathrm{p}<0.05)$. This loss of weight could be attributed to the decrease in feeding habit and other physiologic disturbances cause by exposure to formaldehyde (Table 1). These findings are similar to that observed by Egwurugwu et al., (2017).

Assessment of renal parameters revealed statistically significant duration and dose dependent increase in serum concentrations of urea, and cystacin $\mathrm{C}$ in the formalin exposed rats when compared with the control group (Table 2). The serum levels of these parameters were consistently significant in 4 weeks low dose and 4 weeks high dose exposures when compared with the controls. This result shows that there is a dose dependent toxicity of formaldehyde exposures. Increased concentrations of urea and creatinine are very important markers of nephrotoxicity following formalin exposure (Egwurugwu et al., 2018; Vos et al, 2017; Inci et al., 2013; Olisah et al., 2017). Chronic renal failure (CRF) is characterized by gradual decline in glomerular filtration rate (GFR). GFR is usually monitored by serum creatinine concentration and calculated creatinine clearance using Cockcroft and Gault equation. However, serum creatinine does not increase until the GFR has significantly decreased (about $40 \mathrm{ml} / \mathrm{min} / 1.73 \mathrm{~m}^{2}$ ). This insensitivity could give a false sense of alert and leads to late detection of kidney damage. Serum cystacin $C$ in particular also proved to be among novel markers for detection of early kidney injuries. This study observed that even though the serum electrolytes, urea and creatinine of exposed low dose group were not significant when compared with the control. However, serum cystatin $\mathrm{C}$ was significant indicating an earlier sign of kidney damage.

Many experimental and clinical models have attempted to explain the various ways formalin exerts its nephrotoxic effects. Firstly, oxidation of Formaldehyde to formic acid is catalyzed by many enzymes including NAD-dependent dehydrogenase formaldehyde, xanthine oxidase, catalase, and peroxidase. Increased production of these enzymes for the detoxification of formaldehyde has been associated with increased concentration of urea (Tolba et al., 2016). Formaldehyde exposure has also led to an increase in serum levels of urea, creatinine and reduced urine production (Boj et al., 2003). Increased serum values of creatinine and urea strongly suggest renal failure due to exposure to formalin (Milovanovic et al., 2015, Ihim et al., 2017). Exposure to formaldehyde has been associated with thickened tubular and glomerular basal membranes, congestion of intra-tubular vessels and dilatation of distal tubules, glomerular and tubular degeneration and renal papillary necrosis (Zararsiz et al., 2006). Also, prolonged exposure to formaldehyde can lead to degeneration and necrosis of proximal tubule of the kidney and consequently impaired urinary system (Zararsiz et al., 2007; IARC 2012; Kum et al., 2007). The increase in serum urea concentration among the test group animals might be due to the dehydration effects of formalin exposure. Formalin, a known dehydrating agent, can induce haemoconcentration in the rats leading to increase in urea levels (Ihim et al., 2017; Carl et al., 2008). The exact mechanism for the effect of formalin on serum electrolytes is unclear. However, the following may explain the effects: Formalin exposure has been linked with serious histopathological and biochemical derangements in renal tissues that may lead to oliguria, anuria, and renal failure (Kunak et al., 2015). 
Table 1: The mean weight of albino rats before and after the experiment.

\begin{tabular}{llcc}
\hline Groups & $\begin{array}{l}\text { Average mean weight before } \\
\text { experiment }\end{array}$ & $\begin{array}{l}\text { Average mean weight } \\
\text { after experiment }\end{array}$ & P value \\
\hline A (control) & $121.7 \pm 0.04$ & $146.4 \pm 0.10$ & 0.001 \\
B(4weeks 100ppm) & $119.5 \pm 0.08$ & $116.3 \pm 0.06$ & 0.030 \\
D(4weeks 200ppm) & $120.4 \pm 0.06$ & $112.4 \pm 0.14$ & 0.001 \\
\hline
\end{tabular}

There was a significant reduction in mean weights of rats exposed to formaldehyde when compared with their mean weights before exposure. However, there is an increase in mean weight of control unexposed group after the experimental period when compared with the mean weight before the experiment.

Table 2: The mean levels of kidney markers of Albino rats exposed to formaldehyde at different periods

\begin{tabular}{|c|c|c|c|c|c|c|c|}
\hline $\begin{array}{l}\text { Groups } \\
(\mathbf{n}=10)\end{array}$ & $\mathrm{Na}(\mathrm{mmol} / \mathrm{L})$ & $\mathbf{K}^{+}(\mathbf{m m o l} / \mathbf{L})$ & $\mathrm{Cl}-(\mathrm{mmol} / \mathrm{L})$ & $\mathrm{HCO}_{3}^{-}(\mathrm{mmol} / \mathrm{L})$ & Urea $(\mathrm{mmol} / \mathrm{L})$ & Creat $(\mu \mathrm{mol} / \mathrm{L})$ & Cyst C \\
\hline Control (A) & $143.22 \pm 2.48$ & $3.47 \pm 0.30$ & $101.37 \pm 3.58$ & $23.28 \pm 1.85$ & $3.03 \pm 0.59$ & $71.50 \pm 10.09$ & $171.85 \pm 13.11^{*}$ \\
\hline $\begin{array}{l}\text { Low dose } \\
\text { One months } \\
\text { (B) }\end{array}$ & $143.84 \pm 2.53$ & $3.15 \pm 0.63$ & $102.1 \pm 2.87$ & $22.22 \pm 1.90$ & $3.60 \pm 0.74$ & $74.16 \pm 7.20$ & $187.96 \pm 30.92 *$ \\
\hline $\begin{array}{l}\text { High dose } \\
\text { One } \\
\text { weeks }(C) \\
\text { P value }\end{array}$ & $142.89 \pm 2.023$ & $3.45 \pm 0.23$ & $101.1 \pm 3.67$ & $21.72 \pm 1.60$ & $4.53 \pm 0.84$ & $78.12 \pm 9.20$ & $197.96 \pm 26.92 *$ \\
\hline $\begin{array}{l}\text { POST Hoc } \\
\text { A/B }\end{array}$ & 1.00 & 0.78 & 1.00 & 0.67 & 0.83 & 0.53 & 0.01 \\
\hline $\mathrm{A} / \mathrm{C}$ & 1.00 & 0.80 & 0.90 & 0.73 & 0.01 & 0.02 & 0.01 \\
\hline $\mathrm{B} / \mathrm{C}$ & 0.76 & 0.83 & 0.68 & 0.53 & 0.01 & 0.51 & 0.41 \\
\hline
\end{tabular}

\footnotetext{
* Significant at 0.05 level of significance
}

The effects of formaldehyde exposure on kidney markers of Albino rats were assessed by determining the concentrations of the serum electrolytes, urea, creatinine and cystatin $\mathrm{C}$. When the concentrations of the serum electrolytes, sodium. Potassium, bicarbonate and chloride were compared across the three group, they were not statistically significant. Urea was significantly higher in group $\mathrm{C}$ when compared with low dose B and control group A. Also, when the low dose group B was compared with the high dose group $\mathrm{C}$, it was statistically significant. Creatinine concentrations were significanlty higher in high doses groups $\mathrm{C}$ when compared with the control group A. Finally, the cystatin $\mathrm{C}$ concentrations were also significant when groups $\mathrm{B}, \mathrm{C}$ were compared with the control group.

\section{Conclusion}

Formaldehyde could cause deleterious injury to the kidney An early and gradual decline in renal function may not been detected by conventional serum electrolytes, urea and creatinine as these markers become deranged after significant damage to the renal tissues has been established. Serum cystatin $\mathrm{C}$ may be better marker for early detection of kidney damage.

\section{References}

Boj JR, Marco I, Cortes O, Canalda C. (2003). The acute nephrotoxicity of systemically administered formaldehyde in rats. Eur J Paediatr Dent.;4:1620 .

Carl AB, Edward RA, David EB. Creatinine, urea and uric acid: Laboratory considerations. In: Tietz Fundamentals of Clinical Chemistry, 6th Edition, Saunders Elsevier, New Delhi, India. 2008; 298:363- 366.

Egwurugwu JN, Ohamaeme MC, Izunwanne D, Ugwuezumba PC, Ngwu EE, Elendu MU, Nwamkpa P, Ekweogu CN. (2018). Assessment of the
Inhalational Effects of Formalin on the lipid profile of Wistar Albino rats. Research Journal in Health Sciences; 3(1). $\underline{\text { https://doi.org/10.9734/AJMAH/2018/44412 }}$

Elshaer, N.S.M., Mahmoud M.A.E.. (2017), Toxic effects of formalintreated cadaver on medical students, staff members, and workers in the Alexandria Faculty of Medicine. Alex J Med 54 (4) 1-6. http://dx.doi.org/10.1016/j.ajme.2016.11.006. https://doi.org/10.1016/j.ajme.2016.11.006

Girish V P, Shishirkumar S, Thejeshwari T, Apoorva D. Physical Reactions of Formalin used as Cadaver Preservative on First Year Medical Students (2014) Journal of Evidence Based Medicine and Healthcare 1(5):279-283 https://doi.org/10.18410/jebmh/2014/44

Ihim AC, Ogbodo EC, Oguaka VW, Ozuruoke DFN, Okwara EC, Nwovu AI, Amah UK, Abiodun BE. . (2017). Effect of shortterm exposure to formalin on kidney function tests of students in Nnewi. European Journal of Biomedical and Pharmaceutical Sciences; 4(12):51- 55.

Inci M, Zararsiz I, Davarci M, Gorur S.( 2013). Toxic effects of formaldehyde on the urinary system. Turk J Urol.;39(1): 48-52. https://doi.org/10.5152/tud.2013.010

International Agency for Research on Cancer IARC. Monographs on the evaluation of carcinogenic risks to humans 88, formaldehyde, 2butoxyethanol and I-tert-butoxypropranolol-2-ol. In: IARC. 2006; 36-325.

International Agency for the Research on Cancer (IARC). (2012). Formaldehyde (From Monograph 100F), in a Review of Human Carcinogens: Chemical Agents and Related Occupations: Lyon.

Kum C, Sekkin S, Kiral F, Akar F. Effects of xylene and formaldehyde inhalations on renal oxidative stress and some serum biochemical 
parameters in rats. Toxicol. Ind. Health. 2007;23(2):115-20. https://doi.org/10.1177/0748233707078218

Kunak CS, Ugan RA, Cadirci E, Karakus E, Polat B, Un H, Halici Z, Saritemur M, Atmaca HT, Karaman A. Nephroprotective potential of carnitine against glycerol and contrast-induced kidney injury in rats through modulation of oxidative stress, Egwurugwu et al.; AJMAH, 12(4): 1-11, 2018; Article no.AJMAH.44412 10 proinflammatory cytokines, and apoptosis. Br. J. Radiol. 2015;20140724.

Lauwerys R, Bernard A, Viau C, Buchet JP.(!995) Kidney disorders and haematotoxicity from organic solvent exposure. Scand J Work Environ Health ; 11(1): 83-93.

Lima LF, Murta GL, Bandeira AC, Nardeli CR, Lima WG, Bezerra FS Short-term exposure to formaldehyde promotes oxidative damage and inflammation in the trachea and diaphragm muscle of adult rats. Ann. Anat. 2015;202:45-51

https://doi.org/10.1016/j.aanat.2015.08.003

Linkermann, A., Chen, G., Dong, G., Kunzendorf, U., Krautwald, S., and Dong, Z. (2014). Regulated cell death in AKI. J. Am. Soc. Nephrol. 25, 2689-2701.

https://doi.org/10.1681/ASN.2014030262

Milovanovic V, Buha A, Matovic V, Curcic M, Vucinic S, Nakano T, Antonijevic B.

Oxidative stress and renal toxicity after subacute exposure to decabrominated diphenyl ether in wistar rats. Environ. Sci. Pollut. Res. Int. 2015;1-8.

Onyije FM, Avwioro OG. (2012). Excruciating effects of formaldehyde exposure to students in gross anatomy dissection laboratory. The International Journal of Occupational and Environmental Medicine; 3:9295 .

Olisah, M.C., Meludu S.C., Dioka C.E., Egbuna, C.and Onyekere P. F. (2020). Oxidative Stress Markers and Liver Functions of Morticians Exposed to Formaldehyde in South-Eastern, Nigeria. IOSR Journal of Environmental Science, Toxicology and Food Technology. 14:3:PP 14-18

Olisah MC, Ifemeje JC, Ilechukwu OU, Ofor CC. (2017). Effect of formaldehyde inhalation and alcohol consumption on some kidney markers of Albino rats. Tropical Journal of Applied Natural Sciences, 2(1):98- 101. https://doi.org/10.25240/TJANS.2017.2.1.16

Olisah, M.C, Meludu S.C., Dioka C.E, Onah C.E, Ilechukwu, O.U.(2019). Effect of Exposure of Formaldehyde Vapours on some Oxidative Stress Markers, Total Protein and Albumin in Albino .Rats. Oriental Journal of Science \& Engineering Vol -1, -1.
Tolba AM, Salama AAA. (2016). Adverse effects of melamine formaldehyde on the liver, kidney and brain in rats. Der Pharma Chemica.; 8(2):398-409.

Raja, D.S.(2012). Potential health hazards for students exposed to formaldehyde in the gross anatomy laboratory. Journal Environ Health, 74, 36-40.

Rana, S. V. (2008). Metals and apoptosis: Recent developments. J. Trace Elem. Med. $\quad$ Biol. $22, \quad 284$ https://doi.org/10.1016/j.jtemb.2008.08.002

Ramos CO, Nardeli CR, Campos KKD, Pena KB, Machado DF, Bandeira ACB, Costa, G.P, Talvani, A, Bezerra, F.S (2017). The exposure to formaldehyde causes renal dysfunction, inflammation and redox imbalance in rats. Experimental and Toxicologic Pathology; 69:367-372. https://doi.org/10.1016/j.etp.2017.02.008

Uboh, FE, Ebong, PE, Eka, OU, Eyong,EU, Akpanabiatu, MI. (2005). Effect of inhalation exposure to kerosene and petrol-fumes on some anaemia-diagnostic indices in rats. Global Journal of Environmental $\begin{array}{llll}\text { Sciences } & 4 & \text { (1), } & 59-63\end{array}$ https://doi.org/10.4314/gjes.v4i1.2442

US Environmental Protection Agency (US EPA), (1990) Drinking Water Criteria Document for Toluene Prepared by the Environmental Criteria and Assessment Office of Health and Environmental Assessment US Environmental Protection Agency Cincinnati $\mathrm{OH}$ for the Office of Drinking Water ECAO-CIN-408.

Sancho, M. S. M., Lopez-Novoa, J. M., and Lopez, H. F. J. (2015). Pathophysiological role of different tubular epithelial cell death modes in acute kidney injury. Clin. Kidney J. 8, 548-559. https://doi.org/10.1093/ckj/sfv069

Vos H, Luinstra M, Pauw R. (2017). Survival of a formalin intoxication: A case report. Netherlands Journal of Critical Care; 25(4):133-136.

Zararsiz I, Sarsilmaz M, Tas U, Kus I, Meydan S, Ozan E. Protective effect of melatonin against formaldehyde-induced kidney damage in rats. Toxicol. Ind. Health 2007;23(10):573-9. https://doi.org/10.1177/0748233708089022 editor@ipsintelligentsia.com

- Thank you for publishing with us. 